\title{
Unwanted Pregnancy and Associated Factors Among Nigerian Women
}

CONTEXT: Many Nigerian women experience unwanted pregnancies. To prevent associated health problems, it is important to understand the factors related to unwanted pregnancy in Nigeria.

METHODS: A community-based survey of 2,978 women aged 15-49 was conducted in eight Nigerian states. Univariate analyses and multivariate logistic regression analyses were used to determine the incidence of unwanted pregnancy, the incidence of seeking an abortion among women with unwanted pregnancies and the factors associated with unwanted pregnancy and abortion-seeking behavior. Additional analyses examined the prevalence of contraceptive use and women's reasons for seeking to terminate unwanted pregnancies and for not practicing contraception at the time their unwanted pregnancies were conceived.

RESULTS: Twenty-eight percent of respondents reported ever having had an unwanted pregnancy; of those, half reported having attempted to end their last unwanted pregnancy. Forty-three percent of women who sought an abortion did so because they were not married, were too young or were still in school. Of the women who were not practicing contraception when they had the unwanted pregnancy, $44 \%$ said that they were unaware of family planning, and $22 \%$ that they either did not have access to contraceptive services, services were too expensive or they were afraid of side effects. At the time of the survey, $27 \%$ of all respondents were at risk of an unwanted pregnancy. Almost half were unaware of contraceptive methods.

CONCLUSIONS: Nigerian women often turn to abortion to avoid unwanted births. The provision of family planning counseling and information could substantially reduce the incidence of unwanted pregnancy and induced abortion in Nigeria.

International Family Planning Perspectives, 2006, 32(4):175-184

Studies have consistently indicated that large numbers of Nigerian women experience unwanted or mistimed pregnancies and births. According to a 1997 survey of women in southwestern Nigeria, at least $27 \%$ of women had ever been pregnant when they did not want to be. ${ }^{1}$ Similarly, in a survey conducted in southwestern and northern Nigeria in the mid-1990s, 20\% of women reported ever having experienced an unwanted pregnancy. ${ }^{2}$ The 2003 Demographic and Health Survey (DHS) found that of live births to women in the previous three years, $15 \%$ were reported to be unplanned. ${ }^{3}$ It has been estimated that about $12 \%$ of all pregnancies in Nigeria (not including those that result in spontaneous abortion) end in induced abortion, and another $9 \%$ result in unplanned births. ${ }^{4}$

Unintended pregnancy poses significant public health risks. One consequence of unwanted pregnancy is induced abortion. In the mid-1990s, the abortion rate in Nigeria was estimated at 25 per 1,000 women..$^{5}$ At this rate, approximately 760,000 abortions will occur in 2006. Because abortion is illegal in Nigeria except to save a woman's life, many procedures are conducted under unsafe conditions and carry a substantial risk of maternal morbidity ${ }^{6}$ and mortality. ${ }^{7}$ It is estimated that about $25 \%$ of women who have abortions in Nigeria experience serious complications. ${ }^{8}$
According to national surveys, Nigerian women and couples want fewer children than they once did: Between 1990 and 2003, the mean desired number of children declined from 5.8 to 5.3. ${ }^{9}$ Even so, levels of contraceptive use remain low: In 2003, only $7 \%$ of married women used a modern contraceptive method and another $6 \%$ relied on a traditional or folk method. ${ }^{10}$ The combination of low contraceptive use and smaller desired family size implies high levels of unmet need for family planning in Nigeria. Indeed, among married women of reproductive age, 32\% do not want to have a child in the near future but are not using a modern contraceptive method, and are therefore at risk of an unwanted pregnancy. ${ }^{11}$

Research on reasons for family planning nonuse in Nigeria generally points to women's perceived lack of need for contraception, fear of side effects and opposition to contraception on personal or religious grounds. ${ }^{12}$ Less is known about the circumstances surrounding women's unwanted pregnancies and their reasons for seeking to terminate some of these pregnancies. The limited evidence available from small studies in various parts of Nigeria generally points to such reasons as a wish to space births, economic constraints, the desire to remain in school and not being married. ${ }^{13}$
By Gilda Sedgh, Akinrinola Bankole, Boniface

Oye-Adeniran, Isaac F. Adewole, Susheela Singh and Rubina Hussain

Gilda Sedgh is senior research associate, Akinrinola Bankole is director of international research, Susheela Singh is vice president for research and Rubina Hussain is research associateall with the

Guttmacher Institute, New York. Boniface A. Oye-Adeniran and Isaac F. Adewole are coordinators of The Campaign Against Unwanted Pregnancy, Lagos, Nigeria. 


\begin{tabular}{|c|c|}
\hline Characteristic & $\begin{array}{l}\% \\
(\mathrm{~N}=2,978)\end{array}$ \\
\hline \multicolumn{2}{|l|}{ Age } \\
\hline$<20$ & 16.0 \\
\hline $20-24$ & 22.4 \\
\hline $25-29$ & 18.0 \\
\hline 30-34 & 18.0 \\
\hline $35-39$ & 11.8 \\
\hline$\geq 40$ & 13.8 \\
\hline \multicolumn{2}{|l|}{ Marital status } \\
\hline Never-married & 23.4 \\
\hline Married & 70.0 \\
\hline Divorced/separated/widowed & 6.6 \\
\hline \multicolumn{2}{|l|}{ Parity } \\
\hline 0 & 28.8 \\
\hline $1-3$ & 34.2 \\
\hline$>3$ & 37.0 \\
\hline \multicolumn{2}{|l|}{ Education } \\
\hline None & 31.0 \\
\hline Primary & 31.9 \\
\hline Secondary & 28.2 \\
\hline University & 8.9 \\
\hline \multicolumn{2}{|l|}{ Socioeconomic status } \\
\hline Low & 48.4 \\
\hline Middle & 29.1 \\
\hline High & 22.4 \\
\hline \multicolumn{2}{|l|}{ Religion } \\
\hline Catholic & 20.5 \\
\hline Protestant/Spiritual/Pentecostal & 36.1 \\
\hline Muslim & 42.7 \\
\hline Traditional/other & 0.8 \\
\hline \multicolumn{2}{|l|}{ Residence } \\
\hline Urban & 34.3 \\
\hline Rural & 65.7 \\
\hline \multicolumn{2}{|l|}{ Region } \\
\hline South & 39.9 \\
\hline North & 60.1 \\
\hline \multicolumn{2}{|l|}{ Ever used contraceptive } \\
\hline Modern & 22.1 \\
\hline Traditional & 4.7 \\
\hline None & 73.2 \\
\hline \multicolumn{2}{|l|}{ Currently use contraceptive } \\
\hline Modern & 12.6 \\
\hline Traditional & 4.9 \\
\hline None & 82.5 \\
\hline Total & 100.0 \\
\hline
\end{tabular}

The purpose of this study is to examine the current incidence of unwanted pregnancy among women of reproductive age in eight states in Nigeria and to explore the factors associated with it. We utilize an approach that is designed to minimize underreporting and to elicit reports of all unwanted pregnancies, regardless of their outcomes. In addition, we explore women's reasons for not wanting a pregnancy, the barriers they face to effective contraceptive use, and their use of abortion to terminate unwanted pregnancies. Furthermore, we examine the level of risk of unwanted pregnancy and the reasons given for not practicing contraception by women who are at risk.

Although studies have examined aspects of these issues in certain parts of Nigeria, this study provides a more comprehensive analysis of the circumstances around unwanted pregnancies and covers a broader geographic region. A better understanding of the underlying and more immediate factors associated with unwanted pregnancy can inform the development of programs and policies that will help couples avoid unwanted or mistimed pregnancies.

\section{METHODS Study Design and Sample}

Data for this study come from a community-based, crosssectional survey of women conducted in 2002-2003 in eight states in Nigeria. We selected the states (Ekiti, Gombe, Kano, Kogi, Lagos, Imo, Kaduna and Rivers) so that two states came from each of the country's four health zones (Northeast, Northwest, Southeast and Southwest). The most urban state and the most rural state in each of the health zones were chosen; we used the rural-urban distribution of women in the 1999 Nigeria DHS to make these determinations. ${ }^{14}$ At least one state from each of the country's six geopolitical zones (North-East, North-West, Central, South-East, SouthWest and South-South) is represented in the selection.

From each state, we randomly selected one urban and one rural local government area. Within each local government area, 10 enumeration areas were randomly selected, and within each enumeration area, 20 households were selected for interview using a systematic random sampling approach. We selected one woman aged 15-49 in each household to be interviewed, yielding a total sample size of 3,200 women. In all, 3,020 women were successfully interviewed; of those, we included in our analysis the 2,978 who were aged 15-49. Prior to conducting interviews, the research protocol-including the study design, questionnaire, informed consent procedure and means of preserving respondents' confidentiality-was reviewed and approved by the Guttmacher Institute's Institutional Review Board and by an ethical review panel in Nigeria.

Because the sample design gave equal representation to urban and rural areas, urban residents were oversampled in the survey. This is reflected in a comparison of the distribution in our sample with that of respondents surveyed in the Nigeria DHS in 2003. Also, our respondents were more educated than those interviewed in the DHS, most likely because of the overrepresentation of women from urban areas. To correct for this, we developed and applied a weight factor to adjust the distribution of our sample according to residence, education status and geographic region to reflect that of the 2003 DHS sample. The calculation of the weights is described in greater detail elsewhere. ${ }^{15}$

\section{Questionnaire and Interviews}

Data were collected using a questionnaire administered during face-to-face interviews. Interviewers and field supervisors underwent baseline and follow-up training sessions covering the nature and purpose of the study, the structure and content of the questionnaire, the interview setting, practice interviews and strategies for conducting a good 
interview and solving difficult situations.

Respondents were asked about their social, economic and demographic characteristics. To ascertain women's socioeconomic status, interviewers asked a series of questions about household assets and wealth. Using the approach developed by Filmer and Pritchett, we constructed a wealth index variable indicating the level of wealth in each woman's household. ${ }^{16}$ As in the DHS, women were asked which from a list of nearly 20 material goods (e.g., radio, television, refrigerator and car) their household contained. ${ }^{17}$ We applied a factor analysis to these data and classified respondents into the low, middle and high tertiles of socioeconomic status.

In addition, participants were asked about their pregnancy and fertility behaviors and preferences, contraceptive use history, sexual activity and experiences with unintended pregnancy and induced abortion; however, obtaining information on unwanted pregnancies is difficult. Women may be reluctant to report a birth as unwanted, and may be even more reluctant to discuss unwanted pregnancies that they have terminated.

Our questionnaire led up to these issues by first asking women about other aspects of their reproductive histories, including the numbers of pregnancies and live births they had had, and their knowledge of and experience with contraception. Then, women were asked if they had ever been pregnant when they did not want to be. If they responded in the negative, interviewers approached the issue of unwanted pregnancy again by asking "Has there ever been any time that a pregnancy would have caused difficulties for you because of your circumstances or the opposition of someone else to the pregnancy, even though you may have desired it?" Women who responded affirmatively to either question were deemed to have had an unwanted pregnancy.

Women who reported ever having an unwanted pregnancy were asked if they ever did anything to stop a pregnancy. Only those who responded affirmatively were asked about the circumstances surrounding the most recent instance. To explore why the pregnancy was not wanted, interviewers asked respondents to indicate their reasons for not wanting the pregnancy. They probed respondents about each item from a list of reasons; women were able to specify additional reasons in an open-ended response. Then, interviewers asked respondents to indicate their single most important reason for not wanting the pregnancy. Interviewers inquired whether a contraceptive method was being used when the unwanted pregnancy was conceived, and if so, which method. Women who reported not using a method were asked their reasons for nonuse.

Interviewers asked all respondents about their knowledge of contraceptive methods. Women were asked "Have you heard about ways or methods that women or men can use to delay or avoid pregnancy?" Women who indicated being aware of contraception were asked which methods they had ever used and which they were using at the time of the survey; interviewers did not prompt women about knowledge of specific methods that were not mentioned spontaneously. Interviewers asked nonusers to give their

\begin{tabular}{|c|c|c|c|}
\hline Characteristic & $\begin{array}{l}\% \text { ever had an } \\
\text { unwanted } \\
\text { pregnancy } \\
(\mathrm{N}=2,978)\end{array}$ & $\begin{array}{l}\% \text { ever attempted } \\
\text { to terminate } \\
\text { an unwanted } \\
\text { pregnancyt } \\
(\mathrm{N}=819)\end{array}$ & $\begin{array}{l}\text { Median time since } \\
\text { last abortion } \\
\text { attempt (in yrs.) } \\
(\mathrm{N}=416) \neq\end{array}$ \\
\hline All & 27.7 & 50.9 & 3.0 \\
\hline \multicolumn{4}{|l|}{ Age } \\
\hline$<20$ (ref) & 26.7 & 54.8 & 1.0 \\
\hline $20-24$ & 24.5 & 48.1 & 2.0 \\
\hline $25-29$ & 26.1 & 51.1 & 3.0 \\
\hline 30-34 & 31.1 & 49.4 & 6.0 \\
\hline 35-39 & 31.3 & 54.1 & 7.0 \\
\hline$\geq 40$ & 28.7 & 49.6 & 9.6 \\
\hline \multicolumn{4}{|l|}{ Marital status } \\
\hline Never-married (ref) & 32.8 & 61.7 & 1.5 \\
\hline Married & $26.4^{* * *}$ & $45.4^{* * *}$ & 5.0 \\
\hline Divorced/separated/widowed & $21.9^{* *}$ & 62.8 & 4.0 \\
\hline \multicolumn{4}{|l|}{ Parity } \\
\hline 0 (ref) & 22.6 & 74.3 & 1.9 \\
\hline $1-3$ & $30.0^{* * *}$ & $47.0^{* * *}$ & 4.0 \\
\hline$>3$ & $28.9^{* *}$ & $40.4^{* * *}$ & 6.0 \\
\hline \multicolumn{4}{|l|}{ Education } \\
\hline None (ref) & 22.1 & 38.6 & 4.0 \\
\hline Primary & $30.5^{* * *}$ & 40.1 & 3.0 \\
\hline Secondary & $29.7^{* * *}$ & $66.1^{* * *}$ & 2.0 \\
\hline University & $31.2^{* *}$ & $71.1^{* * *}$ & 5.0 \\
\hline \multicolumn{4}{|l|}{ Socioeconomic status } \\
\hline Low (ref) & 30.1 & 40.7 & 2.0 \\
\hline Middle & $22.7^{* * *}$ & $55.9^{* * *}$ & 3.0 \\
\hline High & 28.5 & $69.3^{* * *}$ & 3.0 \\
\hline \multicolumn{4}{|l|}{ Religion } \\
\hline Catholic (ref) & 49.0 & 48.5 & 2.0 \\
\hline Protestant/Spiritual/Pentecostal & $27.2^{* * *}$ & $56.6^{*}$ & 3.0 \\
\hline Muslim & $17.4^{* * *}$ & 47.3 & 3.8 \\
\hline Traditional/other & $\S$ & $\S$ & $\S$ \\
\hline \multicolumn{4}{|l|}{ Residence } \\
\hline Urban (ref) & 23.5 & 61.1 & 3.0 \\
\hline Rural & $29.7^{* * *}$ & $46.7^{* * *}$ & 3.0 \\
\hline \multicolumn{4}{|l|}{ Region } \\
\hline South (ref) & 28.4 & 62.2 & 4.0 \\
\hline North & 27.1 & $43.1^{* * *}$ & 2.0 \\
\hline \multicolumn{4}{|l|}{ Ever used contraceptive } \\
\hline Modern (ref) & 48.0 & 62.4 & 3.0 \\
\hline Traditional & $37.0^{*}$ & 54.9 & 4.3 \\
\hline None & $20.8^{* * *}$ & $42.2^{* * *}$ & 3.0 \\
\hline \multicolumn{4}{|l|}{ Currently use contraceptive } \\
\hline Modern (ref) & 49.1 & 60.7 & 2.0 \\
\hline Traditional & $37.2^{*}$ & 62.3 & 5.9 \\
\hline None & $23.7^{* * *}$ & $46.8^{* * *}$ & 3.0 \\
\hline
\end{tabular}

${ }^{*} p \leq .05 .{ }^{* *} p \leq .01 .{ }^{* * *} p \leq .001$. Among those who had ever had an unwanted pregnancy. $¥$ Among those who had ever attempted to terminate an unwanted pregnancy. §Not calculated because the sample size was smaller than 25. Note: ref=reference group.

reasons for not practicing contraception, and then to specify the one that was most important.

\section{Data Analysis}

We performed univariate analyses and multivariate logistic regression analyses to determine the prevalence of unwanted pregnancy and the factors associated with that out- 


\begin{tabular}{|c|c|c|c|c|c|c|c|c|c|}
\hline Characteristic & $\begin{array}{l}\text { Not } \\
\text { married }\end{array}$ & $\begin{array}{l}\text { To } \\
\text { stop/space } \\
\text { births }\end{array}$ & $\begin{array}{l}\text { Too } \\
\text { young/in } \\
\text { school }\end{array}$ & $\begin{array}{l}\text { Health } \\
\text { reasons }\end{array}$ & $\begin{array}{l}\text { Economic } \\
\text { reasons }\end{array}$ & $\begin{array}{l}\text { Partner did } \\
\text { not want/left/ } \\
\text { not the father }\end{array}$ & Othert & $\begin{array}{l}\text { Reason } \\
\text { not given }\end{array}$ & Total \\
\hline All & 25.3 & 19.0 & 17.7 & 2.1 & 7.1 & 16.4 & 11.8 & 0.6 & 100.0 \\
\hline \multicolumn{10}{|c|}{ Age at abortion attempt } \\
\hline$<20$ (ref) & 31.0 & 12.9 & 30.2 & 0.0 & 4.3 & 9.5 & 12.1 & 0.0 & 100.0 \\
\hline $20-24$ & 23.1 & 14.3 & 19.8 & 0.0 & 4.4 & 25.3 & 12.1 & 1.1 & 100.0 \\
\hline $25-29^{* *}$ & 26.1 & 8.7 & 11.6 & 4.3 & 8.7 & 26.1 & 14.5 & 0.0 & 100.0 \\
\hline $30-34^{* * *}$ & 10.3 & 33.3 & 7.7 & 2.6 & 5.1 & 20.5 & 20.5 & 0.0 & 100.0 \\
\hline $35-39^{* * *}$ & 11.5 & 46.2 & 0.0 & 0.0 & 26.9 & 7.7 & 7.7 & 0.0 & 100.0 \\
\hline$\geq 40^{* * *}$ & 0.0 & 77.8 & 0.0 & 0.0 & 0.0 & 0.0 & 22.2 & 0.0 & 100.0 \\
\hline \multicolumn{10}{|l|}{ Education } \\
\hline None (ref) & 23.6 & 34.7 & 2.8 & 5.6 & 4.2 & 13.9 & 15.3 & 0.0 & 100.0 \\
\hline Primary & 27.3 & 26.4 & 8.2 & 2.7 & 12.7 & 12.7 & 9.1 & 0.9 & 100.0 \\
\hline Secondary*** & 24.8 & 9.7 & 25.5 & 0.6 & 6.1 & 20.6 & 12.1 & 0.6 & 100.0 \\
\hline University*** & 26.2 & 13.1 & 31.1 & 0.0 & 3.3 & 14.8 & 11.5 & 0.0 & 100.0 \\
\hline \multicolumn{10}{|l|}{ Religion } \\
\hline Catholic (ref) & 34.3 & 14.6 & 16.1 & 2.2 & 6.6 & 19.0 & 7.3 & 0.0 & 100.0 \\
\hline \multicolumn{10}{|c|}{ Protestant/Spiritual/ } \\
\hline Pentecostal & 20.1 & 16.6 & 21.3 & 0.6 & 9.5 & 17.8 & 13.0 & 1.2 & 100.0 \\
\hline Muslim** & 20.4 & 30.6 & 12.2 & 4.1 & 5.1 & 11.2 & 16.3 & 0.0 & 100.0 \\
\hline Traditional/other & $\neq$ & $\neq$ & $\neq$ & $\neq$ & $\neq$ & $\neq$ & $\neq$ & $\neq$ & $\neq$ \\
\hline \multicolumn{10}{|l|}{ Residence } \\
\hline Urban (ref) & 20.7 & 17.9 & 17.2 & 1.4 & 6.2 & 24.1 & 11.7 & 0.7 & 100.0 \\
\hline Rural & 28.1 & 19.4 & 18.3 & 2.7 & 7.6 & 12.2 & 11.4 & 0.4 & 100.0 \\
\hline \multicolumn{10}{|l|}{ Region } \\
\hline South (ref) & 18.3 & 15.0 & 23.0 & 0.5 & 8.5 & 21.6 & 12.7 & 0.5 & 100.0 \\
\hline North*** & 32.7 & 23.5 & 11.7 & 4.1 & 6.1 & 10.7 & 10.7 & 0.5 & 100.0 \\
\hline
\end{tabular}

come. All estimates are weighted. Significance tests were undertaken when appropriate. Because of this study's crosssectional design and the fact that some women's unwanted pregnancies had occurred years before the survey, the associations presented cannot be interpreted as being causal.

\section{RESULTS}

Fifty-six percent of the women were younger than 30 years of age, $70 \%$ were currently married at the time of the survey and $71 \%$ had had at least one live birth (Table 1, page 176). Forty-three percent were Muslim, and 57\% were Christian; the majority lived in rural areas (66\%) and in the north (60\%). Twenty-seven percent reported ever using a contraceptive method ( $22 \%$ a modern method, and $5 \%$ a traditional method), and $18 \%$ reported using a method at the time of the survey (13\% a modern method, and 5\% a traditional method).

\section{Unwanted Pregnancies and Attempted Abortions}

Overall, 28\% of the women reported having experienced an unwanted pregnancy at some point in their lives (Table 2 , page 177). The proportion of respondents who had ever had an unplanned pregnancy was greater among nevermarried women (33\%) than among currently or previously married women (26\% and 22\%, respectively), among women with children (29-30\%) than among those without children (23\%) and among educated women (30-31\%) than among those who were uneducated (22\%). Thirty percent of women of low socioeconomic status had had an unplanned pregnancy, compared with $23 \%$ of women of middle socioeconomic status; $49 \%$ of Catholics had had an unplanned pregnancy, compared with 27\% of other Christians and 17\% of Muslims. Greater proportions of women who reported ever or currently using modern contraceptives had had an unplanned pregnancy, compared with those who had never used or were not currently using a method (48-49\% vs. 21-24\%).

Among women who had ever had an unwanted pregnancy, $51 \%$ ( $14 \%$ of the total sample) reported that they had ever sought to terminate an unwanted pregnancy. A greater proportion of never-married women than of currently married women had tried to obtain an abortion (62\% vs. $45 \%$ ); $74 \%$ of nulliparous women had sought an abortion, compared with $40-47 \%$ of women with children. The proportion of respondents who had sought an abortion was greater among women with a secondary or university-level education than among uneducated women (66\% and $71 \%$, respectively, vs. 39\%) and among women of middle or high socioeconomic status than among those of low socioeconomic status ( $56 \%$ and $69 \%$, respectively, vs. $41 \%$ ). Women living in urban areas were more likely to have sought an abortion than those living in rural areas (61\% vs. $47 \%$ ), and those in the south were more likely to have done so than those living in the north (62\% vs. $43 \%$ ). 
Greater proportions of women who reported ever or currently using modern contraceptives (62\% and 61\%, respectively) than of those who had never or were not currently practicing contraception ( $42 \%$ and $47 \%$, respectively) had sought an abortion.

The median length of time since a woman's last abortion attempt was three years. Not surprisingly, women younger than 20 had sought an abortion more recently than had women aged 40 or older ( 1.0 year vs. 9.6 years). Similarly, the median time since the last abortion attempt was 1.5 years for never-married women, compared with five years for married women.

\section{Reasons for Unwanted Pregnancies}

Overall, the most common primary reason women cited for their most recent attempt to terminate an unwanted pregnancy was being unmarried at the time of the pregnancy (25\%-Table 3). Nineteen percent named stopping childbearing or spacing births as their primary reason (about one-third stopping and two-thirds spacing), 18\% being too young or still in school, and $16 \%$ problems with their partner. Other reasons included economic issues (7\%) and health problems (2\%).

Among 15-19-year-olds, the most frequently cited reasons for last seeking an abortion were being single (31\%) and being too young or still in school (30\%). Thirty-three percent of women aged 30-34 cited stopping or spacing births; this proportion was 46\% for women aged 35-39 and $78 \%$ for those aged 40 or older. Women who had a secondary or university-level education reported being too young or not wanting to interrupt their schooling as their primary reason (26-31\%), whereas women with little or no education cited stopping or spacing births as their primary reason (26-35\%). Among Catholic women, the most important reason for seeking an abortion was not being married (34\%), and the most common reason for Muslim women was to stop or space births (31\%). The distribution of reasons for seeking an abortion did not differ significantly between women in urban and rural areas.

Women were asked to mention reasons other than their primary reason for seeking to end their last unwanted pregnancy. More than half of women who had sought to end their last unwanted pregnancy cited being unmarried when they became pregnant as a primary or other reason (not shown). Nearly half said that their husband or nonmarital partner did not want the pregnancy, one-third that they were too young or still in school, one-third that they were trying stop childbearing or space births and one-fifth that they had economic reasons.

\section{Contraceptive Use}

Among women who had ever sought an abortion, we examined contraceptive use at the time of the most recent unwanted pregnancy. Overall, 16\% reported that they had been using a modern contraceptive method at the time the pregnancy was conceived (Table 4). This proportion generally increased with age, from $9 \%$ among women younger than

\begin{tabular}{|c|c|c|c|c|}
\hline Characteristic & Modern & Traditional & None & Total \\
\hline All & 16.4 & 5.7 & 77.9 & 100.0 \\
\hline \multicolumn{5}{|c|}{ Age at abortion attempt } \\
\hline$<20$ (ref) & 8.6 & 1.7 & 89.7 & 100.0 \\
\hline $20-24^{*}$ & 16.3 & 8.7 & 75.0 & 100.0 \\
\hline $25-29 * * *$ & 23.9 & 10.4 & 65.7 & 100.0 \\
\hline $30-34^{*}$ & 21.1 & 5.3 & 73. & 100.0 \\
\hline $35-39 * *$ & 30.8 & 7.7 & 61.5 & 100.0 \\
\hline$\geq 40$ & 33.3 & 0.0 & 66.7 & 100.0 \\
\hline \multicolumn{5}{|c|}{ No. of live children at abortion attempt } \\
\hline 0 (ref) & 12.8 & 6.9 & 80.3 & 100.0 \\
\hline $1-3$ & 18.9 & 4.4 & 76.7 & 100.0 \\
\hline$>3$ & 21.3 & 4.9 & 73.8 & 100.0 \\
\hline \multicolumn{5}{|l|}{ Education } \\
\hline None (ref) & 17.8 & 0.0 & 82.2 & 100.0 \\
\hline Primary & 12.7 & 2.7 & 84.5 & 100.0 \\
\hline Secondary* & 17.0 & 8.2 & 74.8 & 100.0 \\
\hline University $^{* *}$ & 20.3 & 13.6 & 66.1 & 100.0 \\
\hline \multicolumn{5}{|c|}{ Socioeconomic status } \\
\hline Low (ref) & 13.3 & 0.6 & 86.1 & 100.0 \\
\hline Middle & 15.4 & 2.9 & 81.7 & 100.0 \\
\hline High $^{* * *}$ & 21.6 & 15.2 & 63.2 & 100.0 \\
\hline \multicolumn{5}{|l|}{ Religion } \\
\hline Catholic (ref) & 17.0 & 3.5 & 79.4 & 100.0 \\
\hline \multicolumn{5}{|c|}{ Protestant/Spiritual/ } \\
\hline Pentecostal & 16.8 & 9.3 & 73.9 & 100.0 \\
\hline Muslim & 16.5 & 3.1 & 80.4 & 100.0 \\
\hline Traditional/other & $t$ & $t$ & t & $t$ \\
\hline \multicolumn{5}{|l|}{ Residence } \\
\hline Urban (ref) & 19.0 & 13.9 & 67.2 & 100.0 \\
\hline Rural*** & 15.4 & 1.9 & 82.8 & 100.0 \\
\hline \multicolumn{5}{|l|}{ Region } \\
\hline South (ref) & 14.6 & 9.2 & 76.2 & 100.0 \\
\hline North ${ }^{* *}$ & 18.3 & 2.0 & 79.7 & 100.0 \\
\hline \multicolumn{5}{|c|}{ Ever in union at abortion attempt } \\
\hline No (ref) & 12.2 & 6.6 & 81.2 & 100.0 \\
\hline Yes & 21.4 & 4.8 & 73.8 & 100.0 \\
\hline
\end{tabular}

20 to $33 \%$ among women aged 40 or older. Another $6 \%$ of those who had attempted to terminate an unwanted pregnancy reported that they had been using a traditional contraceptive when the pregnancy was conceived. Women with a university education, those with the highest socioeconomic status and those residing in urban areas were the groups with the greatest proportions using a traditional method when they experienced the unwanted pregnancy (14-15\%). These women were also relatively likely to have used a modern method (19-22\%), suggesting that certain groups are more likely than others to practice contraception overall.

The remaining $78 \%$ of women who had attempted to terminate an unwanted pregnancy reported that they had not been practicing contraception when the pregnancy they last attempted to terminate was conceived. Of those, about 


TABLE 5. Odds ratios from multivariate regression analyses
assessing women's likelihood of ever having had an un-
wanted pregnancy and having sought to terminate an un-
wanted pregnancy, by selected characteristics

${ }^{*} \mathrm{p} \leq .05 .{ }^{* *} \mathrm{p} \leq .01 .{ }^{* * *} \mathrm{p} \leq .001$. †Among women who had had an unwanted pregnancy. ₹Not calculated because the sample size was smaller than 25 .

$44 \%$ indicated that they had not been aware of family planning options (not shown). The other $56 \%$ were asked why they had not used a method at the time, although interviewers did not probe for specific reasons. More than onefifth $(22 \%)$ said that they had not used contraceptives either because they were afraid of side effects, they did not know where to obtain family planning services or the services were too expensive; interviewers did not probe for specific concerns regarding side effects, so it was not possible to determine whether their concerns related to experienced or expected side effects. Another $16 \%$ said that

*We considered women infecund if they had been in a union for at least five years without having had a live birth and had never used a modern contraceptive method, or if they indicated they were pregnant at the time of the survey. they had not practiced contraception because they did not think they would get pregnant.

\section{Multivariate Analyses}

In analyses controlling for social and demographic characteristics, married women were less likely than nevermarried women to report having had an unwanted pregnancy, and separated, divorced or widowed women were more likely to report having had one (odds ratios, 0.5 and 2.6, respectively-Table 5). Women with more than three live births had greater odds than nulliparous women of having had an unwanted pregnancy (2.4). In addition, living in rural areas and living in the north were positively associated with unwanted pregnancy (1.5 each). Compared with Catholics, Muslim and other Christian women had lower odds of having had an unwanted pregnancy (0.2 and 0.4, respectively). Women of middle socioeconomic status were less likely than women of low socioeconomic status to have had an unwanted pregnancy (0.8). Furthermore, women who had ever used a modern contraceptive method or had ever used only a traditional method were more likely than those who had never practiced contraception to have experienced an unwanted pregnancy (3.9 and 2.6, respectively).

Among women who had had an unwanted pregnancy, having a secondary-level education and having ever used a modern contraceptive were the subgroups with the highest odds of ever seeking an induced abortion (odds ratios, 1.9 each). Women who had had at least one child were less likely than those who were nulliparous to have sought an abortion (0.1-0.2) and women living in the north were less likely than those in the south to have done so (0.6).

\section{Women at Risk of Unwanted Pregnancy}

In our analyses, we defined women as being in need of family planning if they had been sexually active in the three months prior to the survey, did not wish to have a child for at least two years or were uncertain when they wanted to have a child and were not infecund. * According to this definition, $40 \%$ of our total sample had a need for family planning (Table 6). The demand for family planning was greatest among women with a university education (52\%) and Catholics (48\%).

Thirteen percent of all women-about a third of women in need of family planning-were using a modern contraceptive method at the time of the survey. Never-married women, those with a university education and those of high socioeconomic status were the most likely to be using a modern method (19-31\%), whereas women younger than 20 , those with no schooling, those of low socioeconomic status and Muslims were the least likely (6-8\%).

Twenty-seven percent of women were at risk of an unwanted pregnancy and thus had an unmet need for modern contraceptives at the time of the survey (defined as those who are sexually active and fecund, do not wish to have a child for at least two years but are not using a modern contraceptive method). The level of unmet need was greatest 
among married women, women with no schooling, those of low socioeconomic status, Catholics and those living in the north (30-31\%); it was lowest among women aged 40 or older, those who were formerly married, those with a university education and those in the south (9-22\%).

Among women with an unmet need for modern contraceptives, nearly half (46\%) were not aware of any method of family planning (not shown). This proportion was as high as $72 \%$ among women younger than 20 and $62 \%$ among women with no schooling. On the other hand, $75 \%$ of urban women and women in the south, and more than $90 \%$ of those with a university education, could name at least one contraceptive method. Among women who were aware of family planning, the most common reason cited for not using a method was that they wanted more children (14\% of all women with an unmet need). Of the women who cited this reason, 29\% had indicated earlier in the survey that they did not want another child at all or for at least 24 months, and $71 \%$ had said they were uncertain if or when they wanted to have another child. The apparent contradiction between their stated fertility preferences and their reason for not practicing contraception most likely reflects their ambivalence or uncertainty regarding future childbearing.

In multivariate analyses, women aged 35-39 and those aged 40 or older had significantly lower odds than 15-19year-olds of being at risk of an unwanted pregnancy (odds ratios, 0.6 and 0.3 , respectively-Table 7, page 182). Although married women were less likely than never-married women to have had an unwanted pregnancy, they had increased odds of being at risk of an unwanted pregnancy at the time of the survey (2.5), possibly because they were much less likely than never-married women to be using modern contraceptives. Alternatively, married women might have been less likely to report a previous pregnancy as unwanted. Catholic women, who were more likely than women of other religious affiliations to have had an unwanted pregnancy and to have sought an induced abortion, were also the religious group most likely to be at risk of unwanted pregnancy. Women in the north were at greater risk of an unwanted pregnancy than those in the south (1.5); these women were more likely than women in the south to have experienced unwanted pregnancies previously, but were less likely to have terminated those pregnancies.

\section{DISCUSSION}

More than one-fourth of all Nigerian women of reproductive age in this survey reported having had an unwanted pregnancy, and half of those reported ever having sought to terminate an unwanted pregnancy. These findings are comparable to those from previous research: In a survey conducted in two states in southwestern and northern Nigeria in 1996, which also used a carefully designed questioning technique, $20 \%$ of women reported having had an unwanted pregnancy and 13\% having ever attempted to obtain an abortion; ${ }^{18}$ the proportion ever having had an unwanted pregnancy was 27\% in a 1997 study conducted in
TABLE 6. Percentages of women in need of family planning,
currently using a modern method and at risk of an unwanted pregnancy, by selected characteristics

\begin{tabular}{llll} 
Characteristic & $\begin{array}{l}\text { In need of } \\
\text { family } \\
\text { planningt }\end{array}$ & $\begin{array}{l}\text { Using modern } \\
\text { method }\end{array}$ & $\begin{array}{l}\text { At risk of } \\
\text { unwanted } \\
\text { pregnancy }\end{array}$ \\
\hline All & $\mathbf{4 0 . 0}$ & $\mathbf{1 2 . 6}$ & $\mathbf{2 6 . 9}$ \\
Age & & & \\
$<20$ (ref) & 36.4 & 6.1 & 29.8 \\
$20-24$ & $43.5^{*}$ & $15.7^{* * *}$ & 27.4 \\
$25-29$ & $42.7^{*}$ & $13.2^{* * *}$ & 29.0 \\
$30-34$ & $43.8^{*}$ & $12.9^{* * *}$ & 30.7 \\
$35-39$ & 40.3 & $14.2^{* * *}$ & 25.9 \\
$\geq 40$ & $29.3^{*}$ & $13.3^{* * *}$ & $16.0^{* * *}$
\end{tabular}

\section{Marital status}

$\begin{array}{llll}\begin{array}{l}\text { Never-married (ref) } \\ \text { Married }\end{array} & 40.4 & 18.5 & 20.9 \\ \begin{array}{l}\text { Divorced/separated/ } \\ \text { widowed }\end{array} & 42.0 & 10.9^{* * *} & 30.9^{* * *} \\ \text { Parity } & 19.2^{* * *} & 9.8^{* *} & 9.3^{* * *} \\ 0 \text { (ref) } & & & \\ 1-3 & 38.5 & 12.2 & 25.5 \\ >3 & 41.0 & 14.0 & 26.7 \\ & 40.4 & 11.5 & 28.8\end{array}$

Education

None (ref)

Primary

Secondary

University

$\begin{array}{lcl}35.3 & 5.7 & 29.5 \\ 39.2 & 9.5^{* *} & 29.4 \\ 42.5^{* *} & 18.0^{* * *} & 24.2^{*} \\ 52.1^{* * *} & 31.2^{* * *} & 20.5^{* *}\end{array}$

Socioeconomic status

Low (ref) 38.2

High

38.2

39.1
$45.4^{* *}$

7.9

$13.4^{* * *}$

30.1

High

Religion

Catholic (ref)

Protestant/Spiritual/

Pentecostal

Muslim

Traditional/other

47.5

17.3

$23.2^{* * *}$

Residence

Urban (ref)

Rural

$39.0^{* * *}$
$37.0^{* * *}$

16.0

$7.3^{* * *}$

Region

South (ref)

$\S$

$\S$

29.4

$\S$

North

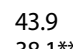

$38.1^{* * *}$

16.9

26.6

27.4

${ }^{*} p \leq .05 .{ }^{* *} p \leq .01 .{ }^{* * * *} p \leq .001$. WWomen who are sexually active and fecund who do not wish to have a child for at least two years. $¥$ Women who are sexually active and fecund, do not wish to have a child for at least two years but are not using a modern contraceptive method. §Not calculated because the sample size was smaller than 25. Note: ref=reference group.

southwestern Nigeria. ${ }^{19}$ Like most population surveys of unwanted pregnancy and abortion, it is likely that the levels observed in our study underestimate the incidence of both events, as some women are unwilling to report having had an unwanted pregnancy or an abortion.

Our findings, as well as those from previous research on this issue, suggest that millions of Nigerian women have confronted an unwanted pregnancy at some point in their lives. An unwanted pregnancy that is carried to term can result in an enormous change in a woman's life, whereas the alternative-an abortion-carries substantial risks of morbidity and even mortality in this country where induced abortion is illegal under most circumstances. 


\begin{tabular}{|c|c|}
\hline Characteristic & Odds ratio \\
\hline \multicolumn{2}{|l|}{ Age } \\
\hline$<20$ (ref) & 1.00 \\
\hline $20-24$ & 0.87 \\
\hline $25-29$ & 0.85 \\
\hline $30-34$ & 0.73 \\
\hline $35-39$ & $0.59^{*}$ \\
\hline$\geq 40$ & $0.28^{* * *}$ \\
\hline \multicolumn{2}{|l|}{ Marital status } \\
\hline Never-married (ref) & 1.00 \\
\hline Married & $2.48^{* * *}$ \\
\hline Divorced/separated/widowed & $1.92^{*}$ \\
\hline \multicolumn{2}{|l|}{ Parity } \\
\hline 0 (ref) & 1.00 \\
\hline $1-3$ & $0.73^{*}$ \\
\hline$>3$ & 1.05 \\
\hline \multicolumn{2}{|l|}{ Education } \\
\hline None (ref) & 1.00 \\
\hline Primary & 1.12 \\
\hline Secondary & 1.03 \\
\hline University & 0.87 \\
\hline \multicolumn{2}{|l|}{ Socioeconomic status } \\
\hline Poorest (ref) & 1.00 \\
\hline Middle & 0.93 \\
\hline Wealthiest & 0.87 \\
\hline \multicolumn{2}{|l|}{ Religion } \\
\hline Catholic (ref) & 1.00 \\
\hline Protestant/Spiritual/Pentecostal & $0.59 * * *$ \\
\hline Muslim & $0.68^{* *}$ \\
\hline Traditional/other & $t$ \\
\hline \multicolumn{2}{|l|}{ Residence } \\
\hline Urban (ref) & 1.00 \\
\hline Rural & 0.81 \\
\hline \multicolumn{2}{|l|}{ Region } \\
\hline South (ref) & 1.00 \\
\hline North & $1.45^{* *}$ \\
\hline
\end{tabular}

The proportion of respondents who had attempted to terminate their last unwanted pregnancy was relatively high among nulliparous women, women who had attended university, nonpoor women and women residing in urban areas. Nearly half of the women who attempted to have an abortion indicated that their main reason for not wanting the pregnancy was that they were not married, were too young or were still in school. These findings paint a picture in which those who seek to end their unwanted pregnancies tend to be young, single women who have a strong motivation to delay the start of childbearing, and wealthy women who both want small families and have access to abortion to control their fertility. Although young women and nevermarried women were not disproportionately represented among respondents who had attempted to have an abortion, women's characteristics at the time of the survey do not necessarily reflect their characteristics at the time of their abortion attempts. Another significant proportion of women who had sought an abortion said that they had wanted to stop having children or to space their births. It appears that older women who want to stop or better manage their childbearing make up another large group who must contend with unwanted pregnancies and the risks associated with unsafe abortion.

An important factor contributing to the high levels of unwanted pregnancy and abortion in Nigeria is the persistently low level of contraceptive use. Despite the fact that women might overreport contraceptive use preceding an abortion to avert blame for the unwanted pregnancy, ${ }^{20}$ more than three-fourths of respondents who attempted to terminate their last unwanted pregnancy indicated that they were not practicing contraception at the time the pregnancy was conceived.

In this study, women were not prompted to indicate their knowledge of specific methods; they might have demonstrated a higher level of awareness with such probing. In the 2003 Nigeria DHS, which did ask women about each specific method, only $21 \%$ of women reported that they did not know any contraceptive method. ${ }^{21}$ However, a woman's ability to spontaneously name one or more contraceptive methods is a more stringent test of awareness and knowledge. Women who report knowledge only when prompted are arguably less knowledgeable and less prepared to actually practice contraception.

Among women who could spontaneously mention at least one contraceptive method, many did not know where to obtain family planning services, lived too far away from a family planning provider or were deterred by methods' side effects. Although some contraceptive methods are in fact associated with side effects, a series of focus group discussions among young Nigerian women revealed that many of the concerns that prevented them from using contraceptives were based on misinformation about the nature of these side effects. ${ }^{22}$

Among women in our sample, $40 \%$ were in need of family planning, including $27 \%$ who had an unmet need and were therefore at risk of an unwanted pregnancy. Of those with unmet need, almost half were unaware of family planning options, whereas 15\% indicated that they were not using contraceptives because of lack of access, fear of side effects or because they did not think they were at risk of pregnancy. These reasons represent barriers that could be overcome by the promotion of family planning and the provision of accessible contraceptive services and counseling.

\section{Program and Policy Implications}

Taken together, our findings point to a great need for multifaceted approaches to increase awareness of, access to and use of contraceptives among Nigerian women. During the late 1980s and early 1990s, following the issuance of a new population policy, some well-publicized efforts were undertaken to expand Nigerian women's and men's knowledge and use of modern contraceptive methods. ${ }^{23}$ These included programs broadcast on television and radio. ${ }^{24} \mathrm{In}$ deed, studies of family planning awareness in regions of Nigeria have found that among women who knew of fam- 
ily planning, the most common source of knowledge was mass media. ${ }^{25}$ These campaigns, however, appear to have had limited success, especially in rural areas that have less access to these sources of information.

Government support for the programs and activities resulting from the 1988 population policy fell far short of the level needed to meet its goals. ${ }^{26}$ In February 2005, a new Policy for National Population and Sustainable Development was released by the Nigerian government. ${ }^{27}$ This policy includes among its aims the promotion of knowledge and use of family planning. If sufficient resources are committed to programs in support of this policy, women and couples will increasingly have the means to prevent unwanted pregnancies.

A major strength of this study is that it presents the experiences of women in all the major regions of Nigeria. Furthermore, it explores not just the proportions of women who have ever had an unwanted pregnancy, have sought an abortion or are at risk of an unwanted pregnancy, but the reasons that underlie them, and the barriers women face to controlling the number and timing of their pregnancies.

The findings of this study confirm that a large proportion of Nigerian women are becoming pregnant when they do not want to. The results also imply that, unless unwanted pregnancies are prevented, many women will turn to abortion to avoid bearing children they are not prepared to have. Policymakers and providers can benefit from the evidence on women's experiences of unwanted pregnancies, abortion and contraception to formulate informed policies and programs that can help women and couples have the number of children they want, when they want them, without facing undue risks to their health.

\section{REFERENCES}

1. Oye-Adeniran BA et al., Community-based survey of unwanted pregnancy in southwestern Nigeria, African Journal of Reproductive Health, 2004, 8(3): 103-115.

2. Okonofua FE et al., Assessing the prevalence and determinants of unwanted pregnancy and induced abortion in Nigeria, Studies in Family Planning, 1999, 30(1):67-77.

3. National Population Commission (NPC), Federal Republic of Nigeria and ORC Macro, Nigeria Demographic and Health Survey 2003, Calverton, MD, USA: NPC and ORC Macro, 2004, p. 104.

4. Henshaw SK et al., The incidence of induced abortion in Nigeria, International Family Planning Perspectives, 1998, 24(4):156-164.

5. Ibid.

6. Makinwa-Adebusoye P, Singh S and Audam S, Nigerian health professionals' perceptions about abortion practice, International Family Planning Perspectives, 1997, 23(4):155-161; Okonofua FE, Induced abortion: a risk factor for secondary infertility in Nigerian women, Journal of Obstetrics \& Gynaecology, 1994, 14(2):272-276; and Ladipo OA, Preventing and managing complications of induced abortion in Third World countries, International Journal of Gynecology \& Obstetrics, 1989, 3(Suppl.):21-31

7. Oye-Adeniran BA, Umoh AV and Nnatu SN, Complications of unsafe abortion: a case study and the need for abortion law reform in Nigeria, Reproductive Health Matters, 2002, 10(19):18-21; and Adewole I, Trends in postabortal mortality and morbidity in Ibadan, Nigeria, International Journal of Gynecology E Obstetrics, 1992, 38(1):115-118.

8. Bankole A et al., Unwanted Pregnancy and Unsafe Abortion in Nigeria: Causes and Consequences, New York: Guttmacher Institute, 2006.
9. Hussain R et al., Reducing unintended pregnancy in Nigeria, Research in Brief, New York: The Alan Guttmacher Institute (AGI), 2005, p. 6.

10. NPC, 2004, op. cit. (see reference 3).

11. Hussain R et al., 2005, op. cit. (see reference 9).

12. NPC, 2004, op. cit. (see reference 3); Orji EO and Onwudiegwu U Prevalence and determinants of contraceptive practice in a defined Nigerian population, Journal of Obstetrics \& Gynaecology, 2002, 22(5):540-543; and Oye-Adeniran BA et al., Contraceptive prevalence among young women in Nigeria, Journal of Obstetrics \& Gynaecology, 2005, 25(2): 182-185.

13. Oye-Adeniran BA et al., 2004, op. cit. (see reference 1); and Okonofua FE et al., 1999, op. cit. (see reference 2).

14. NPC, Nigeria Demographic and Health Survey 1999, Calverton, MD, USA: National Population Commission and ORC Macro, 2000.

15. Bankole A et al., 2005, op. cit. (see reference 8).

16. Filmer D and Pritchett LH, Estimating wealth effects without expenditure data-or tears: an application to educational enrollments in states of India, Demography, 2001, 38(1):115-132.

17. Rutstein SO and Johnson K, The DHS Wealth Index, DHS Comparative Reports, Calverton, MD, USA: ORC Macro, 2004, No. 6.

18. Okonofua FE et al., 1999, op, cit. (see reference 2).

19. Oye-Adeniran BA et al., 2005, op. cit. (see reference 12).

20. Trussell J and Vaughan B, Contraceptive failure, method-related discontinuation and resumption of use: results from the 1995 National Survey of Family Growth, Family Planning Perspectives, 1999, 31(2):6472 .

21. NPC, Federal Republic of Nigeria and ORC Macro, 2004, op. cit. (see reference 3)

22. Otoide VO, Oronsaye F and Okonofua FE, Why Nigerian adolescents seek abortion rather than contraception: evidence from focusgroup discussions, International Family Planning Perspectives, 2001, 27(2):77-81.

23. Feyisetan BJ and Bankole A, Fertility transition in Nigeria: trends and prospects, 2002, <http://www.un.org/esa/population/ publications/completingfertility/RevisedBANKOLEpaper.PDF>, accessed Feb. 23, 2006.

24. Bankole A, Rodríguez $\mathrm{G}$ and Westoff CF, Mass media messages and reproductive behaviour in Nigeria, Journal of Biosocial Science, 1996 28(2):227-239; and Population Communication Services, Nigeria Family Health Services Project Information Education and Communication Component, Two-Year Activities April 1989 to March 1990, Baltimore, MD, USA: Johns Hopkins University, 1990.

25. Bassey EA et al., Awareness, attitude and practice of contraception among secondary school girls in Calabar, Nigeria, Nigerian Journal of Medicine, 2005, 14(2):146-150; and Ozumba BC, Obi SN and Ijioma NN, Knowledge, attitude and practice of modern contraception among single women in a rural and urban community in southeast Nigeria, Journal of Obstetrics \& Gynaecology, 2005, 25(3):292-295.

26. Feyisetan BJ and Bankole A, 2002, op. cit. (see reference 23).

27. Chesa C, Obasanjo urges Nigerians to raise small families, Daily Independent, Feb. 23, 2005.

\section{RESUMEN}

Contexto: Muchas mujeres nigerianas tienen embarazos no deseados. Para prevenir los problemas de salud conexos, es importante conocer los factores relacionados con el embarazo no deseado en Nigeria.

Métodos: Se realizó una encuesta con base en la comunidad en la que participaron 2.978 mujeres de 15-49 años, en ocho estados de Nigeria. Se utilizaron análisis de regresión logística con una variable y con variables múltiples para determinar la incidencia del embarazo no deseado, la incidencia de aborto inducido entre las mujeres con embarazos no deseados, y los 
factores relacionados con los embarazos no deseados y cómo las mujeres procuran un aborto inducido en ese país. Análisis adicionales examinaron la prevalencia del uso de anticonceptivos y las razones por las cuales las mujeres interrumpian un embarazo no deseado, así como las razones por las cuales no practicaban la anticoncepción en el momento en que concibieron estos embarazos no deseados.

Resultados: El 28\% de las participantes indicaron que alguna vez habian tenido un embarazo no deseado; de este grupo, la mitad indicó que había intentado terminar su último embarazo no deseado. El $43 \%$ de las mujeres que recurrían al aborto lo hicieron porque no estaban casadas, eran demasiado jóvenes o aún estaban estudiando. Del grupo de mujeres que no practicaban la anticoncepción en el momento de tener un embarazo no deseado, el 44\% indicaron que no tenían conocimiento de la planificación familiar, y el 22\% que no tenían acceso a los servicios de anticonceptivos, que los anticonceptivos eran demasiado costosos o porque temían los efectos secundarios de los anticonceptivos. En el momento de la encuesta, el 27\% de todas las participantes se encontraban en riesgo de tener un embarazo no deseado. Casi la mitad no conocía ningún método anticonceptivo.

Conclusiones: Las mujeres nigerianas con frecuencia recurren al aborto para evitar nacimientos no deseados. El suministro de servicios de consejería e información sobre planificación familiar podría reducir sustancialmente la incidencia de los embarazos no deseados y los abortos inducidos en Nigeria.

\section{RÉSUMÉ}

Contexte: De nombreuses Nigérianes connaissent des grossesses non désirées. Pour éviter les problèmes de santé qui y sont associés, il importe de comprendre les facteurs liés à la grossesse non désirée au Nigéria.

Méthodes: Une enquête en communauté a été menée auprès de 2.978 femmes de 15 à 49 ans dans huit états nigérians. L'ana- lyse de régression logistique uni-et multivariée a permis de déterminer l'incidence des grossesses non désirées, celle du recours à l'avortement parmi les femmes affectées et les facteurs associés à la grossesse non désirée et au comportement de recours à l'avortement. D'autres analyses examinent la prévalence contraceptive et les raisons invoquées par les femmes quant au recours à l'avortement et à l'absence de pratique contraceptive au moment de la conception non désirée.

Résultats: Vingt-huit pour cent des répondantes ont déclaré avoir connu une grossesse non désirée; la moitié d'entre elles ont déclaré avoir tenté d'interrompre leur dernière grossesse non désirée. Quarante-trois pour cent des femmes ayant recouru à l'avortement ont donné pour raisons qu'elles n'étaient pas mariées, qu'elles étaient trop jeunes ou qu'elles fréquentaient encore l'école. De celles qui ne pratiquaient pas la contraception au moment de la conception non désirée, 44\% ont déclaré ne rien savoir de la planification familiale tandis que 22\% affirmaient ne pas avoir accès à des services de contraception, ne pas pouvoir se les payer ou en redouter les effets secondaires. Au moment de l'enquête, $27 \%$ des répondantes couraient le risque d'une grossesse non désirée. Près de la moitié n'étaient pas sensibilisées aux méthodes contraceptives.

Conclusions: Les Nigérianes recourent souvent à l'avortement pour éviter une naissance non désirée. L'apport de prestations de conseil et d'information sur la planification familiale permettrait de réduire substantiellement l'incidence des grossesses non désirées et de l'avortement au Nigéria.

\section{Acknowledgments}

The research on which this article was based was supported by grants from the John D. and Catherine T. MacArthur Foundation and the Packard Foundation. The authors thank Stanley Henshaw for his valuable advice during the development and implementation of the survey and the analysis of the results.

Author contact: gsedgh@guttmacher.org 